\title{
Demographic analysis of gastrointestinal system bleedings
}

\author{
Gastrointestinal sistem kanamalarının demografik analizi
}

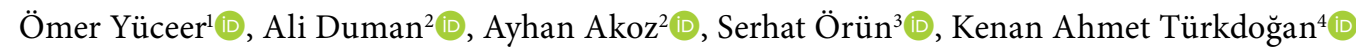 \\ ${ }^{1}$ Department of Emergency Medicine, Kadirli State Hospital, Osmaniye, Turkey \\ ${ }^{2}$ Department of Emergency Medicine, Adnan Menderes University Medical Faculty, Aydin, Turkey \\ ${ }^{3}$ Department of Emergency, Medicine Faculty of Namık Kemal University, Tekirdağ, Turkey \\ ${ }^{4}$ Department of Emergency, Health Ministry University Bağcllar Training and Research Hospital, Istanbul, Turkey
}

\begin{abstract}
Objectives: This study aims to examine patients with gastrointestinal system (GIS) bleeding and evaluate the appropriate treatment methods. Materials and methods: This retrospective study included 164 patients (99 males, 65 females; mean age 66.87 years; range, 21 to 97 years) with GIS bleeding. Demographic characteristics, complaints, habits, duration of hospitalization, and medications used by patients were determined from the files. The effects of hemogram, biochemistry, coagulation, age, gender, and endoscopic findings on mortality were investigated. The effects of endoscopic findings and presence of additional diseases on blood transfusion and other treatment modalities, duration of hospitalization, and mortality were also investigated.

Results: Of the patients with GIS bleeding, $48.8 \%$ applied to our hospital with complaint of melena, $24.4 \%$ of melena and hematemesis, $15.8 \%$ of hematemesis, $6.1 \%$ of hematochezia, and $4.9 \%$ of syncope. Mean duration of hospitalization was $4.65 \pm 4.14$ days. While endoscopy was performed in $98.2 \%$ of the patients, endoscopy could not be performed in $1.8 \%$ of the patients who could not be stabilized.
\end{abstract}

Conclusion: Bleeding control is important to reduce mortality in patients with GIS bleeding. We believe that particularly endoscopic intervention contributes positively in reducing such patients' mortality and morbidity.

Keywords: Endoscopy, gastrointestinal system bleeding, treatment.

$\ddot{o z}$

Amaç: Bu çalışmada gastrointestinal sistem (GiS) kanaması olan hastalar incelendi ve uygun tedavi yöntemleri değerlendirildi.

Gereç ve yöntemler: Bu retrospektif çalışmaya Gis kanaması olan 164 hasta (99 erkek, 65 kadın; ort. yaş 66.87 yıl; dağııı, 21-97 yıl) dahil edildi. Demografik özellikler, yakınmalar, alışkanlıklar, hastanede kalış süresi ve hastaların kullandığı ilaçlar dosyalardan belirlendi. Hemogram, biyokimya, pıhtılaşma, yaş, cinsiyet ve endoskopik bulguların mortalite üzerine etkileri araştııılı. Endoskopik bulguların ve ek hastalıkların varlığının kan transfüzyonu ve diğer tedavi yöntemleri, hastanede kalış süresi ve mortalite üzerine etkileri de araştırıldı.

Bulgular: Gastrointestinal sistem kanaması olan hastaların \%48.8'i melena, \%24.4'ü melena ve hematemez, \%15.8'i hematemez, \%6.1'i hematokezya ve $\% 4.9$ 'u senkop yakınması ile hastanemize başvurdu. Ortalama hastanede kalış süresi $4.65 \pm 4.14$ gündü. Hastaların \%98.2'sine endoskopi yapılırken stabilize edilemeyen hastaların \% 1.8 'ine endoskopi yapılamadı.

Sonuç: Gastrointestinal sistem kanaması olan hastalarda mortaliteyi azaltmak için kanama kontrolü önemlidir. Bu hastaların mortalite ve morbiditelerinin azaltılmasında özellikle endoskopik müdahalenin olumlu katkıda bulunduğuna inanıyoruz.

Anahtar sözcükler: Endoskopi, gastrointestinal sistem kanaması, tedavi.

Acute gastrointestinal system (GIS) bleeding is one of the most commonly encountered gastroenterology emergency conditions.
Gastrointestinal system bleedings are divided into two types as upper and lower GIS bleedings. The bleedings may be obvious or occult. Upper GIS

Received: January 23, 2019 Accepted: January 29, 2019 Published online: February 18, 2019

Correspondence: Serhat Örün, MD. Namık Kemal Üniversitesi Tıp Fakültesi Acil Tıp Anabilim Dalı, 59030, Tekirdağ, Turkey.

Tel: +90 533 - 5136546 e-mail: serhatorun@gmail.com 
bleeding is one of the most common reasons to apply to the emergency service that originates from the mouth and ends at the ligament of Treitz. It is more frequently observed in male patients than female patients and mortality rate increases by advanced age. ${ }^{[1-3]}$ The clinical severity of the upper GIS bleedings, ranging between less severely bleedings to highly serious bleedings, may cause mortality while annual incidence varies approximately between 50 and 172 individuals per 100,000 people. Despite significant improvements in endoscopic and supportive treatments, mortality rate still ranges between $2-15 \%$ while incidence of recurrent bleeding is approximately $10-30 \%$. On the other hand, incidence of lower GIS was reported as 20 per 100,000 people. ${ }^{[2,4]}$ Bleeding may stop spontaneously without recurrence in approximately $80 \%$ of acute upper gastrointestinal bleedings. Morbidity and mortality are more common in the $20 \%$ of the patient population with non-stopping or recurrent bleeding. ${ }^{[5]}$ The detection of these high risk patients is important. It has been accepted that the most noteworthy issue in the treatment of gastrointestinal bleeding is determination of blood transfusion requirement at early stage and an adequate level. ${ }^{[6]}$ It is known that mortality rate is strongly associated with the need for blood transfusion in such patients. ${ }^{[6]}$ Therefore, in this study, we aimed to examine patients with GIS bleeding and evaluate the appropriate treatment methods.

\section{MATERIALS AND METHODS}

This retrospective study included 164 patients (99 males, 65 females; mean age 66.87 years; range, 21 to 97 years) who applied to the Emergency Service of Adnan Menderes University Medical Faculty between January 2016 and June 2016 with a diagnosis of GIS bleeding and were admitted for treatment in the ward or intensive care unit (ICU). Patients' demographic data such as gender and age, test results of blood samples (whole blood count [hemogram], biochemistry test results, and coagulation test values), baseline complaints, addiction history including smoking and alcohol consumption, comorbidities, clinical data such as endoscopy results, administered therapy, duration of hospitalization, and need for blood transfusion were obtained. The relationship between demographic characteristics and mortality was investigated. The study protocol was approved by the Adnan Menderes University Medical Faculty Ethics Committee. A written informed consent was obtained from each patient. The study was conducted in accordance with the principles of the Declaration of Helsinki.

\section{Statistical analysis}

The parameters were analyzed using the PASW version 18.0 software (IBM Comp., Armonk, NY, USA). The results were expressed as numbers and percentile. The percentiles were provided with 95\% confidence interval (CI). Normality was tested with Kolmogorov-Smirnov test while chi-square test was used for statistical analysis of the one-variable data. The results were analyzed within a CI of $95 \%$ and a significance level of $\mathrm{p}=0.05$ (Table 1).

\section{RESULTS}

The baseline complaints of the patients with GIS bleeding were melena, melena with concurrent hematemesis, hematemesis, hematochezia, and syncope in $48.8 \%, 24.4 \%, 15.8 \%, 6.1 \%$, and $4.9 \%$ of the patients, respectively. Of the cases, $30.4 \%$ had no addiction whereas addictions of smoking, alcohol consumption, and both smoking and alcohol consumption were found in 48.9\%, $9.1 \%$, and $11.6 \%$ of the patients, respectively. Mean admission duration was $4.65 \pm 4.14$ days. Time intervals of admission were 1-4 days, 5-10 days, 11-15 days, 16-20 days, and longer than 20 days in $37 \%, 37 \%, 8 \%, 9 \%$, and $9 \%$ of the patients, respectively.

The patients who applied to our hospital received various treatment protocols based on their needs. Treatment protocols involving proton-pump inhibitor (PPI)+hydration+fresh frozen plasma (FFP), PPI+erythrocyte infusion (EI)+FFP, hydration, EI, PPI+hydration, PPI+EI, $\mathrm{PPI}+$ hydration+EI and other medications were administered in 55.5\%, 0.6\%, 0.6\%, 1.8\%, 4.9\%, $18.9 \%, 9.8 \%, 4.9 \%$, and $2.4 \%$ of the patients. Proton-pump inhibitors are the most commonly administered medications in the treatment of patients with GIS bleeding by $56 \%$ whereas the most rarely used treatments protocols were $\mathrm{PPI}+$ hydration+FFP and PPI+EI+FFP by $0.6 \%$. Eighty-seven point two percent of the patients who were admitted with a complaint of GIS bleeding were discharged. Only $12.8 \%$ of those became exitus. Mean duration of hospitalization 
Table 1. General characteristics of patients with gastrointestinal bleeding

\begin{tabular}{lcc}
\hline & $\mathrm{n}$ & $\%$ \\
\hline Gender & & \\
$\quad$ Female & 65 & 40 \\
$\quad$ Male & 99 & 60 \\
Addictions & & \\
$\quad$ Smoking & 80 & 48.8 \\
Alcohol consumption & 15 & 9.1 \\
$\quad$ Smoking + alcohol & 19 & 11.6 \\
$\quad$ None & 50 & 30.5 \\
Baseline complaint & & \\
$\quad$ Melena & 80 & 48.8 \\
Hematemesis & 26 & 15.8 \\
Melena + hematemesis & 40 & 24.4 \\
Hematochezia & 10 & 6.1 \\
Syncope & 8 & 4.9 \\
\hline
\end{tabular}

of female patients was 9.62 days and this time interval included 2.14 days of ICU admission and 7.48 days of ward admission. Mean duration of hospitalization of male patients was 7.23 days and this time interval included 2.40 days of ICU admission and 4.83 days of ward admission. There was no statistically significant difference between genders in terms of admission durations in the hospital, ICU, and ward.

Endoscopic examination was performed in 161 patients who applied with GIS bleeding whereas endoscopy could be conducted in three patients with instable clinical condition. The admission durations in the hospital, ICU, and ward were statistically analyzed within a CI of $95 \%$ and a significance level of $p=0.05$ in patients who underwent or could not undergo endoscopic examination and a statistically significant difference was found. These differences were determined by using t-test. The improvement rate in patients who underwent endoscopic examination was higher than those who could not be performed endoscopic examination. Mean admission durations in the ward and ICU were five and two days, respectively, in patients who were discharged after treatment of GIS bleeding.

Mean admission durations of patients who became exitus in the ward or the ICU were 15.28 days and 7.61 days, respectively, while mean overall admission duration of these patients was 22.89 days. The admission durations in the hospital, ICU, and ward were statistically analyzed within a CI of $95 \%$ and a significance level of $p=0.05$ in patients who were discharged or became exitus and a statistically significant difference was found. These differences were determined by using t-test. Prolonged admission duration in the hospital negatively affected the prognosis. Mean difference between hemoglobin values before treatment of GIS bleeding and at the time of discharge was $0.79 \mathrm{~g} / \mathrm{dL}$ while that difference was found as $1.08 \mathrm{~g} / \mathrm{dL}$ in the exitus patients. The elevation in the hemoglobin levels at baseline and after treatment in the discharged or exitus patients was statistically analyzed and no statistically significant difference was determined.

\section{DISCUSSION}

Gastrointestinal system bleeding is currently an important health problem with a mortality rate of $10 \%$ despite the diagnostic and therapeutic improvements in the treatment process administered in the ICU. ${ }^{77-10]}$ Incidence of GIS bleedings ranges between 50 and 150 per 100,000 applications to hospitals. ${ }^{[7]}$ In our study, $60 \%$ of the patients were males while $40 \%$ were females. This ratio was similar in the other studies on GIS bleedings. ${ }^{[11-13]}$

Gastrointestinal system bleedings may be occult or obvious. Obvious bleedings appear as hematemesis, melena, or hematochezia. ${ }^{[14,15]}$ Similar to our findings, Lewis et al. ${ }^{[16]}$ have reported melena as the most common complaint by $48 \%$ in their study. Melena was also reported as the most common complaint in a study of Adamopoulos et al. ${ }^{[1]}$

Alcohol consumption and cigarette smoking have significant influence in the development of peptic ulcer which is an important reason for upper GIS bleedings. Use of steroid and non-steroid anti-inflammatory drugs in patients with addiction of alcohol consumption and cigarette smoking increases their negative impact on GIS bleedings. ${ }^{[16-18]}$ Aksöz et al. ${ }^{[19]}$ have detected addictions of cigarette smoking and alcohol consumption in $33.2 \%$ and $16.9 \%$ of the patients, respectively. In our study, 49\%, 9\%, and $12 \%$ of the patients had addictions of cigarette smoking, alcohol consumption, and cigarette smoking concurrently with alcohol consumption, respectively, whereas $30 \%$ of the patients had none of these addictions. 
In our study, mean duration of hospitalization was five days. It was detected that $37 \%$ of the patients were discharged in the first four days. Of the patients who applied to our hospital, 98.2\% $(\mathrm{n}=161)$ underwent endoscopic examinations whereas $1.8 \%(n=3)$ could not undergo endoscopic examination. A comparison of these groups for the elapsed time in the ICU and clinical service revealed a statistically significant difference between them. The elapsed times in the ICU and clinical service of patients who underwent endoscopic examination were shorter than those who could not undergo endoscopy. Therefore, we believe that the duration of hospitalization is affected by the severity of the clinical condition, comorbidity, and administered treatment protocols of patients.

In their study, Okutur et al. ${ }^{[20]}$ reported no statistically significant difference between patients' hemoglobin values. Likewise, we did not detect any statistically significant difference between the baseline and final hemoglobin values of patients who were discharged or became exitus. Our outcomes comply with the previous studies in the literature. Various mortality rates have been reported in patients with GIS bleeding by different medical centers. ${ }^{[21,22]}$ We have demonstrated a mortality rate of $12.8 \%$ in our study.

The main limitation of this study was the single-centered and retrospective study design. Also, our sample size was relatively small and study duration was limited.

In conclusion, a rapid decision should be established in the diagnosis and regulation of the appropriate treatment procedures in patients with GIS bleeding. We believe that comorbidities should also be treated as well as achieving bleeding control to minimize the mortality rate. Particularly elderly patients with comorbidities should be monitored in the ICU.

\section{Acknowledgements}

The authors would like to thank everyone involved in the study, the emergency physicians, and the medical personnel.

\section{Declaration of conflicting interests}

The authors declared no conflicts of interest with respect to the authorship and/or publication of this article.

\section{Funding}

The authors received no financial support for the research and/or authorship of this article.

\section{REFERENCES}

1. Adamopoulos AB, Baibas NM, Efstathiou SP, Tsioulos DI, Mitromaras AG, Tsami AA, et al. Differentiation between patients with acute upper gastrointestinal bleeding who need early urgent upper gastrointestinal endoscopy and those who do not. A prospective study. Eur J Gastroenterol Hepatol 2003;15:381-7.

2. Alkım H, Şaşmaz N. Akut üst gastrointestinal sistem kanaması. In: Özden A, Şahin B, Yılmaz U, Soykan İ, editörler. Gastroenteroloji. 1. Baskı. Ankara: Fersa Matbaacillk; 2002. s. 141-8.

3. Fleischer D. Etiology and prevalence of severe persistent upper gastrointestinal bleeding. Gastroenterology 1983;84:538-43.

4. Laine L, Peterson WL. Bleeding peptic ulcer. N Engl J Med 1994;331:717-27.

5. Feldman M, Friedman LS, Sleisenger MH. Sleisenger $\mathrm{BF}$, Sleisenger MH, Feldman M. Sleisenger and Fordtran's Gastrointestinal and Liver Disease: Pathophysiology, Diagnosis, Management. 7th ed. Philadelphia: Saunders; 2011.

6. Rosen AM, Fleischer DE. Upper GI bleeding in the elderly: diagnosis and management. Geriatrics 1989;44:26-8.

7. Gilbert DA. Epidemiology of upper gastrointestinal bleeding. Gastrointest Endosc 1990;36:8-13.

8. Lanza F, Rack MF, Simon TJ, Lombardi A, Reyes $\mathrm{R}$, Suryawanshi S. Effects of alendronate on gastric and duodenal mucosa. Am J Gastroenterol 1998;93:753-7.

9. Lau JY, Barkun A, Fan DM, Kuipers EJ, Yang YS, Chan FK. Challenges in the management of acute peptic ulcer bleeding. Lancet 2013;381:2033-43.

10. Lin HJ, Wang K, Perng CL, Chua RT, Lee FY, Lee $\mathrm{CH}$, et al. Early or delayed endoscopy for patients with peptic ulcer bleeding. A prospective randomized study. J Clin Gastroenterol 1996;22:267-71.

11. Chan FK, Sung JJ, Suen R, Lee YT, Wu JC, Leung WK, et al. Does eradication of Helicobacter pylori impair healing of nonsteroidal anti-inflammatory drug associated bleeding peptic ulcers? A prospective randomized study. Aliment Pharmacol Ther 1998;12:1201-5.

12. Farooq FT, Lee MH, Das A, Dixit R, Wong RC. Clinical triage decision vs risk scores in predicting the need for endotherapy in upper gastrointestinal bleeding. Am J Emerg Med 2012;30:129-34.

13. Shorr RI, Ray WA, Daugherty JR, Griffin MR. Concurrent use of nonsteroidal anti-inflammatory drugs and oral anticoagulants places elderly persons at high risk for hemorrhagic peptic ulcer disease. Arch Intern Med 1993;153:1665-70.

14. Podolsky DK, Isselbacher K. Gastrointestinal diseases. In: Fauci AS, Braunwald E, Kasper DL, Hauser SL, Longo DL, Jameson JL, et al., editors. Harrison's Principles of Internal Medicine. 15th ed. New York: McGraw-Hill; 2004. p. 1649-65. 
15. RamírezF, Cifuentes C, Mavares J, Voso J, Monasterios $W$, Hinestrosa $H$, et al. Upper gastrointestinal hemorrhage. Prospective analysis of 741 cases. G E N 1993;47:139-44. [Abstract]

16. Lewis JD, Shin EJ, Metz DC. Characterization of gastrointestinal bleeding in severely ill hospitalized patients. Crit Care Med 2000;28:46-50.

17. Miño Fugarolas G, Jaramillo Esteban JL, Gálvez Calderón C, Carmona Ibáñez C, Reyes López A, De la Mata. An analysis of a general prospective series of 3270 upper digestive hemorrhages. Rev Esp Enferm Dig 1992;82:7-15. [Abstract]

18. Moshkowitz M, Brill S, Konikoff FM, Averbuch M, Arber N, Halpern Z. Additive deleterious effect of smoking on gastroduodenal pathology and clinical course in Helicobacter pylori-positive dyspeptic patients. Isr Med Assoc J 2000;2:892-5.

19. Aksöz K, Ünsal B, Akyol Z. Üst gastrointestinal kanamalı 2568 hastanın değerlendirilmesi. Turk J Gastroenterol 1995;6:262-4.

20. Okutur SK, Alkım C, Bes C, Akut üst gastrointestinal sistem kanamaları: 230 olgunun analizi. Akademik Gastroenteroloji Dergisi 2007;6:30-6.

21. Krämer SC, Görich J, Rilinger N, Siech M, Aschoff AJ, Vogel J, et al. Embolization for gastrointestinal hemorrhages. Eur Radiol 2000;10:802-5.

22. Thomopoulos KC, Vagenas KA, Vagianos CE, Margaritis VG, Blikas AP, Katsakoulis EC, et al. Changes in aetiology and clinical outcome of acute upper gastrointestinal bleeding during the last 15 years. Eur J Gastroenterol Hepatol 2004; $16: 177-82$ 